\title{
Problematika Beragama di Indonesia: Potret Persepsi Masyarakat Terhadap Otoritas Fatwa Majelis Ulama Indonesia
}

\author{
Rohidin \\ Fakultas Hukum Universitas Islam Indonesia \\ Jl. Tamansiswa 158 Yogyakarta \\ rohidin@fh.uii.ac.id.
}

\begin{abstract}
This study focused on the assessment of public perception on fatwa of The Council of Indonesian 'Ulama' (MUI) about the religious cult in Indonesia who has become quite intense public debate. Various responses to that fatwa, on the one side create a religious life in Indonesia more dynamic, but on the other side, the public misunderstanding to the status of a fatwa making religious life became disturbed. This research included in the qualitative research tradition. The main characteristic of this research is the way of observation and data collection performed in the background or natural setting, Based on the results of research in the field, the public perception on fatwa of The Council of Indonesian 'Ulama' (MUI) inferential into three views: First, exclusive category, those in support to the fatwa with all the consequences (taken for granted). Second, inclusive-moderate category, those in support to the fatwa with record does not affect to the civil rights who has been deceive. Third, inclusive-extreme category, those who refuse for any reason (apriori).
\end{abstract}

Key words: Religious problems, public perception, fatwa authority

\begin{abstract}
Abstrak
Penelitian ini difokuskan pada pengkajian persepsi masyarakat terhadap fatwa Majelis Ulama Indonesia (MUI) tentang aliran sesat keagamaan di Indonesia yang selama ini menjadi perdebatan publik yang cukup inten. Beragam tanggapan atas fatwa tersebut, di satu sisi menciptakan kehidupan keberagamaan di Indonesia semakin dinamis, tetapi di lain sisi kesalahpahaman masyarakat atas status fatwa membuat kehidupan keberagamaan menjadi terganggu. Penelitian ini termasuk dalam tradisi penelitian kualitatif. Ciri utama dari penelitian ini adalah cara pengamatan dan pengumpulan datanya dilakukan dalam latar atau setting alamiah, Berdasarkan hasil penelitian di lapangan, persepsi masyarakat terhadap fatwa Majelis Ulama Indonesia (MUI) dapat disimpulkan menjadi tiga pandangan: Pertama, kelompok eksklusif yaitu mereka yang mendukung fatwa dengan segala konsekuensinya (taken for granted). Kedua, kelompok inklusif-moderat yaitu mereka yang mendukung fatwa dengan beberapa catatan. Ketiga, kelompok inklusif-ekstrem, yaitu mereka yang menolak fatwa dengan alasan apapun (apriori).
\end{abstract}

Kata kunci : Problematika beragama, persepsi masyarakat, otoritas fatwa 


\section{Pendahuluan}

Akhir-akhir ini fenomena kebebasan beragama semakin memburuk jika dibandingkan dengan era sebelum reformasi. ${ }^{1}$ Pengusiran, kekerasan, ancaman, dan pemaksaan baik fisik maupun psikologis terhadap penganut agama atau aliranaliran keagamaan tertentu serta penghancuran tempat-tempat ibadah semakin sering tejadi. Pelanggaran-pelanggaran kebebasan beragama tersebut sepertinya tidak pernah berkurang dan bahkan di beberapa daerah justru didukung oleh institusiinstitusi pemerintah maupun non-pemerintah.

Padahal komitmen pemerintah Indonesia terhadap penjaminan kebebasan beragama dan berkeyakinan tampak semakin mengalami kemajuan secara signifikan setelah era reformasi terutama setelah dilakukannya . Pada amandemen kedua UUD 1945, Majelis Permusyawaratan Rakyat (MPR) telah memasukan satu Bab yang secara khusus memberi landasan penjaminan HAM bagi setiap warga negara, yakni BAB X A. Pada Bab ini, terdapat sepuluh pasal tentang HAM yang hampir seluruhnya mengadopsi prinsip-prinsip Deklarasi Universal Hak Asasi Manusia (DUHAM) dan Covenant on Civil and Political Rights (ICCPR).

Salah satu hak asasi yang diatur dalam Bab ini menyangkut hak dan kebebasan beragama dan berkeyakinan bagi setiap warga negara, seperti yang diatur dalam Pasal 28 E UUD 1945. Pasal ini menegaskan tentang cakupan hak beragama dan berkeyakinan, yakni hak untuk memeluk agama, hak untuk menganut satu keyakinan dan hak untuk beribadah menurut agama dan keyakinan tersebut. Hal ini berarti bahwa setiap warga negara memiliki hak yang sama dalam ketiga aspek tersebut. ${ }^{2}$

Jaminan konstitusi mengenai hak-hak ini diperkuat pula oleh beberapa instrumen perundang-undangan di bawah UUD 1945. Undang-undang dimaksud antara lain: Undang-undang No. 39 Tahun 1999 tentang Hak Asasi Manusia terutama Pasal 4, Pasal 12 dan Pasal 22. Undang-undang No. 23 Tahun 2002 tentang perlindungan anak sebagaimana yang diatur dalam Pasal 6 dan Pasal 43 ayat (1). Undang-Undang No. 12 Tahun 2005 tentang Ratifikasi ICCPR terutama yang diatur dalam Pasal 18, 20 dan 27. ${ }^{3}$

\footnotetext{
${ }^{1}$ Minggu 6 Februari 2011 Jamaah Ahmadiyah Cikeusik diserang massa. Akibat dari penyerangan itu 3 (tiga) orang tewas dan 5 orang lainnya luka parang. Selasa 8 Februari 2011 sekitar pukul 10.20 ratusan masa yang masih tersulut emosi ketidakpuasan atas tuntutan Jaksa di Pengadilan Negeri Temanggung, melampiaskan ketidakpuasannya itu dengan cara merusak 2 (dua) gereja, yakni Brthel Indonesia dan Pantekosta.

${ }^{2}$ Ahmad Suaedy, et.al., Islam, Konstitusi dan Hak Asasi Manusia, Problematika Hak Kebebasan Beragama dan Berkeyakinan di Indonesia, The Wahid Institute, Jakarta, 2009, hlm. 40.

${ }^{3}$ Pasal 18 ayat (1) UU No. 12 Tahun 2005 ada tiga hak yang dijamin yakni kebebasan berpikir, beragama dan berkeyakinan. Apabila di dalam Pasal 18 DUHAM, kebebasan berkeyakinan tidak diatur, maka dalam Pasal 18 (1)
} 
Hak kebebasan beragama merupakan salah satu hak yang tidak dapat dibatasi dalam keadaan apapun (non-derogable rights). Sementara kebebasan menjalankan agama adalah hak yang dapat dibatasi (derogable rights), karena berkaitan dengan hak-hak orang lain. ${ }^{4}$

Meskipun pembatasan kebebasan beragama sudah diatur secara jelas oleh instrumen internasional, yakni untuk melindungi lima keamanan yang diperlukan masyarakat, oleh UUD 1945 Pasal 28 J ditambah satu aspek yakni untuk melindungi nilai-nilai agama. Pasal inilah yang kemudian mengundang kritik dari kalangan pegiat HAM terkait dengan nilai-nilai agama yang mana yang harus di lindungi. Kritik pegiat HAM terhadap pasal ini dapat dimaklumi, karena bagi mereka yang terpenting adalah melindungi individu-individu penganut agamanya dan bukan pada agama yang diyakininya. Berbeda dengan pegiat HAM partikular terutama kalangan Islam, pembatasan seperti itu masih dimungkinkan sepanjang dilakukan oleh undang-undang, semata-mata untuk menjamin pengakuan serta penghormatan atas hak kebebasan orang lain dan untuk memenuhi tuntutan yang adil sesuai dengan pertimbangan nilai-nilai agama.

Menurut pegiat HAM partikular, Pasal 28 J UUD 1945 sesungguhnya telah sejalan dengan berbagai instrumen internasional yang telah diratifikasi pemerintah Indonesia. Dengan cara berpikir seperti ini, apabila Undang-Undang No. 1/PNPS/ 1965 itu dipandang sebagai salah satu pembatasan yang dilakukan dengan UU, maka hal ini sebenarnya tidak bertentangan dengan UUD 1945, karena adanya peluang yang diberikan oleh Pasal $28 \mathrm{~J}$ tersebut yang harus dibaca sebagai bagian tidak terpisahkan dari pasal-pasal dalam peraturan lainnya. Latar belakang yang mendasari dikeluarkannya Undang-Undang No. 1 PNPS/1965 tidak terlepas dari aspek ideologis, dan aspek sosial kemasyarakatan keagamaan atau sosio-religius. Dengan kata lain, adalah ironis, ketika sebuah negara yang masyarakatnya beragama tidak ada perangkat hukum yang menjamin, melindungi agama dari perbuatan penyimpangan dan menodai agama bahkan ajaran-ajaran untuk tidak memeluk agama yang banyak menimbulkan bahaya bagi persatuan nasional dan bahaya bagi agama serta ketentraman beragama. Pasal 1 UU No. 1 PNPS/1965 tersebut berbunyi “Setiap orang dilarang dengan sengaja di muka umum menceritakan, menganjurkan

ICCPR, kebebasan keyakinan ini dianggap sebagai salah satu hak yang sederajat dengan kebebasan beragama. Ketiga hak ini dalam kovenan diakui sebagai hak yang tidak dapat dikurangi, bahkan dalam keadaan darurat publik sekalipun, sebagaimana dinyatakan di dalam Pasa 4 ayat (2) kovenan ini.

${ }^{4}$ Lihat Pasal 18 ayat (3) ICCPR. 
atau mengusahakan dukungan umum untuk melakukan penafsiran tentang sesuatu agama yang dianut di Indonesia atau melakukan kegiatan-kegiatan keagamaan dari agama itu, penafsiran dan kegiatan mana menyimpang dari pokok-pokok ajaran agama itu".

Kalimat "penafsiran dan kegiatan mana menyimpang dari pokok-pokok agama” berarti mengamanatkan adanya institusi atau lembaga yang berwenang untuk menentukan tafsir mana yang benar dan mana yang menyimpang. Amanat ini kemudian diberikan kepada Majelis Ulama Indonesia (MUI) selaku lembaga pemegang otoritas tafsir agama (khususnya Islam) di Indonesia. ${ }^{5}$

Menurut sebagian pegiat HAM, pasal tersebut dapat digunakan oleh MUI dan beberapa aliran keagamaan lainnya untuk melarang pengakuan hukum terhadap agama dan keyakinan yang baru berkembang dan untuk mengancam aliran agama atau kepercayaan yang dinilai menyimpang dari mainstream ajaran agama tertentu. Pasal ini menurut mereka sangat problematik karena bertentangan dengan pengakuan kebebasan beragama sebagaimana yang telah diatur dalam undangundang. ${ }^{6}$

Sebagai contoh, The Wahid Institute mengeluarkan Annual Report Kebebasan Beragama dan Kehidupan Keagamaan di Indonesia Tahun 2009, dengan judul “Tindakan Intoleransi Berdasar Agama dan Keyakinan”, menjelaskan bahwa sepanjang 2009, peristiwa intoleransi terjadi sebanyak 93 kasus. Kasus terbanyak terjadi pada Juni dan November 2009, masing-masing 11 peristiwa. Setelah itu berturut-turut Januari ( 9 peristiwa), Febuari ( 9 peristiwa), Maret (8 peristiwa), April (5 peristiwa), Mei (9 peristiwa), Juli (6 peristiwa), Agustus (8 peristiwa), September (5 peristiwa), Oktober (5 peristiwa) dan Desember (7 peristiwa). Adapun dari enam pelaku ormas keagamaan yang banyak melakukan tindakan intoleransi adalah MUI baik tingkat Pusat maupun Daerah dengan 12 tindakan -umumnya dalam bentuk fatwa sesat terhadap sejumlah kelompok keagamaan atau kepercayaan. ${ }^{7}$

${ }^{5}$ Semenjak pertama kali didirikan, MUI dan juga lembaga-lembaga keagamaan lainnya seperti dimaksudkan untuk menjadi perpanjangan tangan dari instrumen rezim otoriter Orde Baru (translating government policy) untuk menyangga kekuasaan dan menjinakkan (baca: mengontrol) setiap bentuk gerakan keagamaan dari "agama-agama tidak resmi” dan masyarakat atau kelompok masyarakat pada umumnya. Lihat John Olle “The Campign Against 'Heresy' State and Society in Negotiation in Indonesia", makalah yang disampaikan dalam $16^{\text {th }}$ Biennial Conference of the Asian Studies Association of Australia di Wollongong pada 26-29 Juni 2009, hlm. 8.

${ }^{6} \mathrm{Al}$ Khanif, Hukum Kebebasan dan Kebebasan Bergama Di Indonesia, LaksBang Mediatama, Yogyakarta, $2010 \mathrm{hlm}$. 227.

${ }^{7}$ The Wahid Institute, “Anual Report Kebebasan Beragama dan Kehidupan Keagamaan di Indonesia Tahun 2009" hlm, 4-5. 
Senada dengan Wahid Institute, Setara Institute dalam Tiga Tahun Kondisi Kebebasan Beragama/Berkeyakinan di Indonesia 2007-2009 melaporkan bahwa dari 291 tindakan pelanggaran, sejumlah 152 kasus merupakan tindakan yang dilakukan warga negara dalam bentuk 86 tindakan kriminal, dan 66 kasus berupa intoleransi yang dilakukan individu maupun lembaga. Kategori tindakan kriminal dan intolernasional tersebut merupakan bentuk pelanggaran hukum tindak pidana. Pelaku tindakan pelanggaran terbanyak pada kategori ini tercacat diantaranya adalah 29 kasus di lakukan MUI terkait dengan fatwa sesat. ${ }^{8}$

Fenomena hak kebebasan beragama dalam konteks Indonesia menghadapi problem konseptual dan praktis yang dilematis. Di satu sisi kebebasan berpendapat, berkeyakinan dan beragama mendapatkan jaminan konstitusional sebagai bagian dari HAM universal - di mana Indonesia menjadi salah satu negara yang meratifikasi ICCPR $^{9}$. Di sisi lain konstitusi dan instrumen peraturan perundangan-undangan lainnya masih membatasi hak kebebasan berpendapat, berkeyakinan dan beragama sebagai hak kodrat yang dimiliki setiap individu.

\section{Rumusan Masalah}

Pertama, bagaimana persepsi masyarakat terhadap fatwa MUI tentang aliran sesat keagamaan di Indonesia? Kedua, bagaimana seharusnya memposisikan fatwa di negara hukum Indonesia?

\section{Tujuan Penelitian}

Berangkat dari pertanyaan penelitian tersebut, maka tujuan yang ingin dicapai dari penelitian ini adalah pertama, untuk memahami dan menganalisis persepsi masyarakat terhadap fatwa MUI tentang aliran sesat keagamaan di Indonesia. Kedua, untuk menemukan alasan-alasan atau argumentasi hukum yang digunakan mereka kemudian memposisikannya dalam negara hukum Indonesia.

\footnotetext{
${ }^{8}$ Setara Institute, "Tiga Tahun Laporan Kondisi Kebebasan Bergama/ Berkeyakinan di Indonesia", hlm. iii

${ }^{9}$ Ratifikasi tersebut dituangkan dalam Undang Undang Nomor 11 Tahun 2005 dalam Lembaran Negara Republik Indonesia Tahun 2005 Nomor 118, Tambahan Lembaran Negara Republik Indonesia Nomor 4557.
} 


\section{Metode Penelitian}

Penelitian ini termasuk penelitian kualitatif. Ciri utama dari penelitian ini adalah cara pengamatan dan pengumpulan datanya dilakukan dalam latar atau setting alamiah, artinya tanpa memanipulasi subyek yang diteliti (sebagaimana adanya natur). Melalui metode ini diharapkan dapat ditemukan makna-makna yang tersembunyi di balik objek maupun subjek yang akan diteliti. Dalam penelitian model ini yang diutamakan adalah key-person atau informan yang jumlahnya tidak ditentukan secara terbatas melainkan mengalir seperti bola salju (snowball). Instrumen penelitian adalah peneliti itu sendiri. Pada penelitian kualitatif interpretif atau konstruktivis maka motif penelitian adalah untuk (1) to explore (2) to critizise (3) to understand. ${ }^{10}$

Beberapa key-person atau informan yang dimintai keterangan berasal dari 3 (tiga) propinsi yakni, Daerah Istimewa Yogyakarta, Jawa Barat dan Jakarta. Cara penentuan key-person atau informan dipilih secara sengaja sesuai dengan tujuan penelitian yang telah dirumuskan. Permaslah dicari dari penelitian ini adalah pandangan atau persepsi dan sikap individu yang pernah terlibat dalam advokasi atau memberikan komentar-komentar terhadap hak kebebasan beragama di Indonesia, serta individu-individu dari organisasi atau aliran yang pernah disesatkan.

Jenis data yang dipergunakan dalam penelitian ini terdiri atas data primer dan data sekunder. Data primer merupakan data yang diambil dari temuan di lapangan, terutama hasil wawancara mendalam dengan key-person atau informan yang behasil diwawancarai sebanyak 16 key-person atau informan; dari kelompok pegiat HAM (5 orang), MUI (3 orang) akademisi (2 orang), aparat penegak hukum (1 orang) dan orang-orang yang pernah terganggu hak kebebasan beragamanya (3 orang) dan masyarakat umum yang pernah terlibat dalam gerakan-gerakan anti kebebasan beragama (2 orang). Data sekunder merupakan data kepustakaan yang menjadi pendukung dari temuan di lapangan yang terdiri dari buku-buku, penelitian sebelumnya, dan dokumen-dokumen organisasi serta kliping media massa.

${ }^{10}$ Suteki, "Rekonstruksi Politik Hukum Tentang Hak Menguasai Negara Atas Sumber Daya Air Berbasis Nilai Keadilan Sosial (Studi Privatisasi Pengelolaan Sumber Daya Air”. Disertasi pada Program Doktor Ilmu Hukum Universitas Diponegoro Semarang, 2008, hlm. 28-29. 


\section{Hasil dan Pembahasan}

\section{Persepsi Masyarakat terhadap Fatwa}

Dalam pandangan konstruktivisme, manusia sebagai mahluk sosial (homo socius) merupakan individual yang dikonstruksikan melalui sebuah realitas sosial, yang selanjutnya akan melahirkan paham inter-subjektivitas. Pemahaman akan hal ini hanya dapat dilakukan oleh individu manakala ia berada dalam proses interaksi sosial yang akan melahirkan sebuah tindakan sosial dan selanjutnya akan menciptakan lingkungan atau realitas sosial yang diinginkan. ${ }^{11}$ Dengan kata lain, sesungguhnya realitas sosial merupakan hasil konstruksi dari proses interaksi tersebut. Di sini, faktor identitas individu menjadi sangat penting dalam menjelaskan kepentingan dari masing-masing individu. Dari pandangan tersebut, secara tidak langsung setiap gagasan yang muncul dari setiap individu tidak akan pernah hampa dari faktor-faktor yang melatarbelakanginya. ${ }^{12}$

Jika mengacu kepada teori-teori tindakan individu di atas kemudian digunakan untuk memotret fatwa-fatwa sesat yang dikeluarkan oleh kalangan MUI, maka menjadi hal yang wajar jika kemudian fatwa-fatwa tersebut ditanggapi secara beragam oleh masyarakat luas. Ragam persepsi ini selanjutnya peneliti kategorikan ke dalam tiga kelompok, yaitu eksklusif, inklusif-moderat, dan inklusif-liberal.

\section{Eksklusif}

Beberapa nama yang termasuk dalam kelompok eksklusif ${ }^{13}$ ini di antaranya adalah: Amirsyah, Adian Husaini, Didin Hafidhuddin, Kamaluddin Ningrat (MUI Yogyakarta) dan Malik Madani (MUI Pusat). Kelompok eksklusif adalah kelompok yang menolak pernyataan bahwa fatwa MUI tentang aliran sesat keagamaan di Indonesia itu telah melanggar HAM, khususnya hak kebebasan beragama. HAM, menurut kelompok ini, tidak identik dengan boleh merusak kedaulatan suatu agama, sebab jika atas

\footnotetext{
${ }^{11}$ Meilani Kasim, "Latar Belakang_Lahirnya Aliran Konstruktivisme” dalam http://meilanikasim. wordpress.com/2011/02/01/latar-belakang-lahirnya-aliran-konstruktivisme/, (Diakses pada tanggal 21 Maret 2011).

${ }^{12}$ Lihat pula perspektif Weber tentang Tindakan Individu dan Blumer tentang interaksionalisme simbolik.

${ }^{13}$ Secara sederhana, eksklusifisme dapat dimaknai sebagi sebuah paham atau sikap yang menganggap bahwa hanya pandangan kelompok dan agamanya saja yang paling benar, sedangkan kelompok yang lain dianggap salah, sesat, dan tidak dapat menjadi jalan keselamatan. Sikap ini didasarkan pada sebuah klaim kebenaran yang ada pada setiap agama, dan merupakan pandangan yang dominan dari zaman ke zaman. Lihat, Adeng Muchtar Ghazali, Agama dan Keberagamaan dalam Konteks Perbandingan Agama, Pustaka Setia, Bandung, 2004, hlm. 152. Lihat juga dalam, Zuhairi Misrawi, Al-Qur'an Kitab Toleransi: Inklusivisme, Pluralisme, dan Multikulturalisme, Fitrah, Jakarta, 2007, hlm. 198.
} 
nama HAM, kemudian merusak nilai-nilai agama, jelas hal itu tidak benar. Oleh karena itu, apa yang dilakukan MUI, sudah berada di jalur yang tepat. ${ }^{14}$ Masalah fatwa tidak jauh berbeda dengan diagnosa penyakit oleh dokter. Pihak yang dapat mendiagnosa sebuah aliran sesat atau tidak adalah lembaga yang punya kompetensi di bidang itu. Komnas HAM, menurutnya, jelas tidak punya hak untuk menyatakan sebuah aliran itu sesat atau tidak, sebab lembaga ini tidak berkompeten di bidang ini. Pihak yang berkompeten hanya ada pada Komisi Fatwa MUI, Majelis Tarjih Muhammadiyah, Bahtsul Masail NU, dan Dewan Hisbah Persatuan Islam atau PERSIS.

Menurut Adian Husaini, dalam Islam, tugas ulama adalah melanjutkan misi kenabian, yakni menjelaskan mana yang halal dan mana yang haram; mana yang tauhid dan mana yang syirik; mana yang lurus dan mana yang sesat; serta mana yang iman dan mana yang kufur. Jika ulama tidak menjalankan tugasnya seperti itu, maka ia sejatinya bukan ulama sebagaimana diamanahkan dalam Islam. Jadi, menurutnya, kalau MUI tidak menjelaskan mana aliran sesat dan mana yang lurus, justru MUI tidak menjalankan fungsi dan tugasnya sebagai ulama. ${ }^{15}$ Mereka menilai bahwa perusakan akidah yang dilakukan beberapa aliran keagamaan di Indonesia terhadap umat Islam justru lebih berat.

Proteksi atas kemurnian ajaran akidah sebagaimana yang dilakukan oleh MUI sebenarnya bukan hal yang baru dan aneh. Agama-agama besar (baca: mainstream) di muka bumi ini seperti Yahudi dan Nasrani akan melakukan hal yang samamenyesatkan apabila ada aliran dalam lingkungan imannya yang dianggap menyimpang dari ajaran pokok. Dalam urusan penjagaan terhadap ajaran-ajaran pokok keagamaan, Vatikan memiliki prosedur yang cukup ketat. Sejumlah Teolog Katolik telah dipecat oleh Vatikan karena memiliki pandangan yang berbeda dengan pandangan resmi Vatikan. Kasus terkenal, misalnya, menimpa Jacques Dupuis SJ., sarjana di Gregorian University Roma, yang diberi sanksi menyusul penerbitan bukunya pada 1997 yang berjudul Toward a Christian Theology of Religious Pluralism.

Terkait dengan otoritas dan status fatwa dalam tata hukum di Indonesia, kelompok ini mengatakan bahwa sekalipun fatwa itu hanya sebatas legal opinion, tidak memiliki daya ikat seperti keputusan pengadilan agama atau yurisprudensi. Namun demikian, perlu diingat bahwa kekuatan fatwa ini akan menjadi riil, manakala dikaitkan

\footnotetext{
${ }^{14}$ Penyataan ini disampaikan oleh Amirsyah, anggota MUI, wawancara paada tanggal 1 Pebruari 2010. Wawancara dengan Adian Huasaini, wawancara pada tanggal 11 Mei 2010.

${ }^{15}$ Wawancara dengan Adian Husaini pada tanggal 11 Mei 2010. Periksa juga, Adian Husaini, Pluralisme Agama: Fatwa MUI yang Tegas \& Tidak Kontroversial, Pustaka Al-Kautsar, Jakarta, 2005, hlm. 26.
} 
dengan UU No. 1/PNPS/1965 tentang Pencegahan Penyalahgunaan atau Penodaan Agama yang status hukumnya kemudian ditingkatnya menjadi UU No. 5 Tahun 1969.

Dalam Pasal 1 Undang-Undang tersebut terdapat kalimat " penafsiran dan kegiatan mana menyimpang dari pokok-pokok ajaran agama itu", menurutnya harus pula dipahami bahwa untuk menentukan ajaran itu menyimpang atau tidak diperlukan institusi atau lembaga yang berkompeten, dan dalam sistem ketatanegaraan seperti di Indonesia, negara tidak berwenang untuk menentukan itu. Sekalipun dalam penjelasan Undang-Undang tersebut dikatakan bahwa, "Dengan kata-kata "kegiatan keagamaan" dimaksudkan segala macam kegiatan yang bersifat keagamaan, misalnya menamakan suatu aliran sebagai agama, mempergunakan istilah-istilah dalam menjalankan atau mengamalkan ajaran-ajaran kepercayaannya ataupun melakukan ibadahnya dan sebagainya. Pokok-pokok ajaran agama dapat diketahui oleh Departemen Agama yang untuk itu mempunyai alat-alat/ cara-cara untuk menyelidikinya".

Kata-kata "mempunyai alat-alat/ cara-cara untuk menyelidikinya", dapat saja diartikan bahwa yang melakukan itu bukan Departemen Agama, tetapi lembaga lain yang dibentuk secara langsung maupun tidak langsung oleh Deapartemen Agama, seperti MUI, Dewan Gereja Indonesia (DGI), Konfrensi Wali Gereja Indonesia (KWI), Perwakilan Umat Budha Indonesia (Walubi), Parisada Hindu Dharma Indonesia PHDI dan Himpunan Penghayat Kepercayaan terhadap Tuhan Yang Maha Esa (HPK). Dalam konteks seperti ini, posisi MUI dalam kaitannya dengan kewenangan mengeluarkan fatwa untuk menilai sebuah aliran itu sesat atau tidak menjadi sangat strategis. Fatwa akan menjadi salah satu dasar pertimbangan penting bagi lembaga penegak hukum seperti Kejaksaan ketika akan mengeluarkan larangan terhadap aliran keagamaan atau kepercayaan yang dinilainya sebagai ajaran yang sesat.

\section{Inklusif-Moderat}

Di antara tokoh-tokoh yang termasuk dalam kelompok Inklusif-Moderat ${ }^{16}$ ini adalah M. Amin Abdullah, Frans Magniz Suseno, dan Masdar Farid Mas'udi. Bagi kelompok ini, MUI sebagai "representasi" elit ulama dalam Islam memiliki hak untuk menentukan aliran seimannya yang berbeda penafsiran dalam akidah. Hal

\footnotetext{
${ }^{16}$ Inklusif di sini, mengacu pada pendapat Nurcholish Madjid, dimaknai sebagai suatu sikap yang memandang bahwa agama-agama lain adalah bentuk implisit agama kita. Lihat Nurcholish Madjid, "Dialog Di antara Ahli Kitab" Pengantar dalam George B. Grose dan Benjamin B. Hubbard, Tiga Agama Satu Tuhan: Sebuah Dialog, terj. Santi Indra Astuti, Mizan, Bandung, 1998, hlm.xix.
} 
ini seperti yang disampaikan oleh Frans Magnis-Suseno ${ }^{17}$ ketika mengelaborasi kata "penafsiran" dalam UU No. 1/PNPS/1965. Beliau berpendapat bahwa arti kata menyimpang memiliki nada aktif, artinya menyimpang dari jalan yang benar. Lain halnya dengan istilah “berbeda”, kata ini lebih netral. Dari sini terlihat bahwa istilah menyimpang adalah istilah yang relatif. Artinya yang memakai kata "menyimpang" adalah pihak yang merasa benar dan sebaliknya bagi mereka yang tadi disebut menyimpang, mereka sendiri menganggap diri benar dan mereka menganggapnya menyimpang sebagai tidak benar. Istilah netral adalah dua pihak itu berbeda. Jadi ajaran B yang secara objektif berbeda dari ajaran A, oleh pihak A dinilai menyimpang, sedangkan bagi pihak B, ajaran A-lah yang menyimpang. Istilah menyimpang dengan sendirinya berpihak. Hal itu mempunyai dua implikasi. Pertama, kata "menyimpang" hanya dapat dipakai atau boleh dipakai oleh "orang dalam", gereja Katolik dapat dan juga sering menyatakan ajaran saksi "Yehova" sebagai menyimpang dari ajaran Kristiani, misalnya. Kedua, "orang luar" tidak dapat mengatakan demikian, dia hanya dapat mengatakan bahwa ajaran Kristiani saksi "Yehova" sangat berbeda dari ajaran gereja Katolik, dan juga berlaku saksi "Yehova" dapat menyatakan gereja Katolik menyimpang.

Penilaian terhadap praktik keagamaan meyimpang atau tidak bukan pada tempatnya di wilayah publik negara. Penilaian menyimpang memuat penilaian bahwa yang disebut menyimpang berada di jalan tidak benar. Padahal penilaian tidak benar hanya masuk akal atas dasar klaim kebenaran, negara tidak berkompeten sama sekali untuk memutuskan, apakah yang benar gereja Katolik atau saksi "Yehova" misalnya? Meskipun mungkin pengikut Katolik seratus kali lebih banyak dibandingkan dengan penganut Kristen saksi “Yehova”. Dua-duanya mengklaim dirinya benar dan yang lain menyimpang. Padahal, satu-satunya yang berhak untuk menyatakan kebenaran mutlak adalah Tuhan. Lembaga yang merasa dapat menentukan mana yang objektif benar, sesungguhnya sudah menempatkan dirinya di tempat Tuhan, dan ini tidak boleh terjadi. ${ }^{18}$

Senada dengan hal di atas, dalam menanggapi kehadiran fatwa sesat oleh MUI ini, adalah M. Amin Abdullah. Ia menawarkan ulang tiga pandangan: ${ }^{19}$ Pertama,

\footnotetext{
${ }^{17}$ Disampaikan dalam diskusi terbatas di Wabid Institute, Jakarta, pada tanggal 10 Maret 2010.

${ }^{18} \mathrm{Hal}$ senada diungkapkan oleh Masdar Farid Mas’udi dalam dengar pendapat Komisi VIII DPR RI dengan para tokoh agama pada 17 Februari 2011 di Jakarta. Menurut Masdar, akhir-akhir ini agama di Indonesia lebih banyak memberikan petaka daripada rahmat. Hal ini salah satunya diakibatkan karena maraknya penyesatan atas keberadaan kelompok lain yang kemudian berujung pada beragam aksi kekerasan.

${ }^{19}$ Wawancara dengan M. Amin Abdullah, Guru Besar dan Mantan Rektor UIN Sunan Kalijaga Yogyakarta pada 17 November 2010 di Komplek UIN Sunan Kalijaga.
} 
bahwa fatwa merupakan bagian dari legal opinion, yang di dalamnya dapat jadi mengandung dissenting opinion (pendapat yang berbeda). Karenanya, keluarnya sebuah fatwa juga harus menghargai kemungkinan adanya dissenting opinion tersebut. Kedua, pada tataran ideal, fatwa yang akan dikeluarkan seharusnya melalui dialog atau debat publik yang melibatkan banyak kalangan. Amin menilai hal ini sangat penting agar fatwa yang akan dikeluarkan lebih menghargai HAM dan mengakomodir nilai-nilai humanistik karena pada akhirnya fatwa tidak lagi menjadi sepihak. Ketiga, perlunya dibangun civil society. Hal ini dianggap penting mengingat fatwa hanya dapat diterapkan secara tepat (on the track) pada masyarakat yang menghargai pendapat orang lain yang berbeda, dan itu hanya mungkin terwujud pada masyarakat yang berbasis civil society.

Inti persoalan yang hendak disampaikan oleh Amin dalam memandang fatwa ini sebenarnya adalah bahwa para pembuat fatwa seharusnya tidak perlu mengajak (baca: meminta dukungan) negara untuk turut menindak kelompok yang diklaim sesat sebab hal itu bukanlah wilayah kerja dari negara. Satu-satunya tugas negara dalam hal ini adalah menjaga dan menjamin keamanan bagi setiap warga negara dari gangguang orang atau kelompok lain.

Dalam konteks kebebasan beragama, pertimbangan itu menunjukkan penilaian bahwa suatu ajaran penafsiran menyimpang dari pokok-pokok ajaran suatu agama tidak ada dalam kompetensi negara, itu ada dalam kompetensi agama yang bersangkutan, misalnya MUI. Apabila negara melakukannya, negara telah melanggar kewajibannya untuk bersiksap netral. Itu berarti juga bahwa tidak dapat dibenarkan suatu ajaran dilarang hanya karena dinilai menyimpang. Jika memang akan dilarang, maka seharusnya negara membatasi kebebasan beragama dan keyakinan masyarakatnya.

\section{Inklusif-Liberal}

Menurut sebagian masyarakat bahwa fatwa MUI tentang aliran sesat keagamaan merupakan problem tersendiri dan telah melanggar basis-basis moral keislaman universal serta bertentangan dengan HAM dan konstitusi. Kelompok ini diwakili oleh para pegiat HAM, seperti Hanik (ICRP), Febi Yonesta (LBH Jakarta), Rumadi (Wahid Institute), Ulil Abshar Abdalla (JIL), Luthfi As-Syaukanie (JIL), dan Abdul Munir Mulkhan (Komnas HAM).

Menurut Hanick, ${ }^{20}$ fatwa tersebut semakin problematis karena MUI juga meminta negara, dalam hal ini pemerintah, untuk melarang penyebaran aliran yang

\footnotetext{
${ }^{20}$ Wawancara pada 2 Pebruari 2010 di Jakarta.
} 
disesatkannya, membekukan organisasi, serta menutup semua tempat kegiatannya. Padahal, kebebasan berpikir, berkeyakinan, dan beragama telah diatur dalam berbagai kovenan internasional, khususnya dalam ICCPR Pasal 1 dan 2 serta dalam konstitusi Indonesia, seperti yang terdapat dalam Pasal 28 E ayat (1), (2) dan (3) UUD 1945.

Terkait dengan hak-hak ini, UUD 1945 lebih lanjut menegaskan bahwa "hak hidup, hak kemerdekaan pikiran dan hati nurani, hak beragama, hak untuk tidak diperbudak, hak untuk diakui sebagai pribadi di hadapan hukum, dan hak untuk tidak dituntut atas dasar hukum yang berlaku surut adalah hak asasi manusia yang tidak dapat dikurangi dalam keadaan apapun" ${ }^{21}$ Dengan demikian, hak beragama merupakan salah satu hak yang tidak dapat dikurangi dalam keadaan apapun (nonderograble rights).

Kemudian, apakah kebebasan beragama itu dapat dilakukan sebebas-bebasnya, tanpa batasan apapun? Para pegiat HAM mengatakan bahwa, kebebasan yang sebebas-bebasnya itu hanya ada di forum internum, kebebasan beragama dalam bentuk kebebasan untuk mewujudkan, mengimplementasikan, atau memanifestasikan agama atau keyakinan seseorang, seperti tindakan berdakwah atau menyebarkan agama atau keyakinan dan mendirikan tempat ibadah digolongkan dalam kebebasan bertindak (freedom to act). Kebebasan beragama dalam bentuk ini diperbolehkan untuk dibatasi dan bersifat dapat diatur atau ditangguhkan pelaksanaannya. Namun, perlu dicatat, bahwa penundaan pelaksanaan, pembatasan atau pengaturan itu hanya diperbolehkan berdasarkan undang-undang. Adapun alasan ini hanya dibenarkan untuk semata-mata perlindungan atas lima hal, yaitu: public safety; public order; public helth; public morals; dan protection of rights and freedom of others. ${ }^{22}$ Dengan demikian tujuan utama tindakan penundaan pelaksanaan, pengaturan atau pembatasan itu adalah untuk menangkal ancaman terhadap keselamatan manusia atau hak milik mereka. ${ }^{23}$

Prinsip seperti ini ditegaskan pula oleh UUD 1945 dalam Pasal 28 J ayat (2) yang berbunyi: “Dalam menjalankan hak dan kebebasannya, setiap orang wajib tunduk kepada pembatasan yang ditetapkan dengan undang-undang dengan maksud semata-mata untuk menjamin pengakuan serta penghormatan atas hak dan

\footnotetext{
${ }^{21}$ Lihat Pasal 28 I, UUD 1945, bandingkan dengan, Pasal 4 UU No. 39 tahun 1999 tentang Hak Asasi Manusia. ${ }^{22}$ Lihat, Pasal 18 ayat (3) ICCPR.

${ }^{23}$ Wawancara dengan Hanick, Aktivis ICPR pada tanggal 2 Pebruari 2010 di Jakarta.
} 
kebebasan orang lain dan untuk memenuhi tuntutan yang adil sesuai dengan pertimbangan moral, nilai-nilai agama, keamanan, dan ketertiban umum dalam suatu masyarakat demokratis".

Berkaitan dengan pasal ini, Hanick berusaha untuk mempertanyakan maksud dan tujuan pembatasan dengan nilai-nilai agama. Di samping karena akan memperumit implementasi hak kebebasan beragama di Indonesia, juga pembatasan seperti ini harus mengindahkan penjelasan-penjelasan yang terdapat dalam instrumen internasional seperti Komentar Umum ICCPR No. 22. Menurut Komentar Umum pembatasan yang diterapkan harus dijamin oleh hukum dan tidak boleh diterapkan dengan cara-cara yang dapat melanggar hak-hak yang dijamin oleh Pasal 18 Kovenan Hak Sipil dan Politik. Komite Hak Asasi Manusia mengamati bahwa Pasal 18 ayat (3) harus diartikan secara tegas. Pembatasan tidak boleh didasarkan pada hal-hal yang tidak dinyatakan dalam Pasal tersebut, walaupun jika alasan tersebut diperkenankan sebagai pembatasan terhadap hak-hak lain yang dilindungi oleh kovenan, keamanan nasional, misalnya. Pembatasan-pembatasan dapat diterapkan hanya untuk tujuan-tujuan sebagaimana yang telah diatur serta harus berhubungan langsung dan sesuai dengan kebutuhan khusus yang sudah ditentukan. Pembatasan tidak boleh diterapkan untuk tujuan-tujuan yang diskriminatif atau diterapkan dengan cara yang diskriminatif. ${ }^{24}$

Berkaitan dengan pembatasan oleh undang-undang, seperti oleh UU No. 1/ PNPS/1965, apakah boleh dilakukan dan dibenarkan undang-undang tersebut telah mendiskreditkan atau bahkan mendiskriminasikan beberapa aliran keagamaan? Terhadap persoalan ini mereka sependapat bahwa pembatasan seperti ini sudah termasuk pelanggaran nilai-nilai dasar HAM. Pasal 1 undang-undang ini pada pokoknya berisi tentang larangan untuk melakukan penafsiran yang menyimpang dari pokok-pokok ajaran agama.

Menurut kelompok ini, perbedaan penafsiran keagamaan merupakan keniscayaan. Otoritas tafsir tidak hanya dimiliki oleh seseorang atau suatu lembaga, oleh karena itu, kebenaran tafsir bersifat relatif dan tidak pernah dan tak akan pernah ada tafsir tunggal. Pemahaman ahli ilmu tafsir dan keislaman selalu beragam, bahkan dapat jadi saling bertentangan. Dalam keadaan seperti ini, justru Nabi Muhammad saw., menggambarkan sebagai situasi yang penuh rahmat, dengan catatan setiap pihak bersedia untuk berdialog dan membangun toleransi keagamaan

${ }^{24}$ Ibid., Lihat juga, Komentar Umum No. 22 paragrap 8. 
bagi kemuliaan kemanusiaan, bukan mengubah keyakinan dengan cara klaim-klaim sepihak seperti sekarang ini. ${ }^{25}$

Perbedaan ini tidak hanya pada wilayah cabang (furû́iyyah), melainkan juga dapat terjadi pada wilayah pokok (ucûlî). Perbedaan penafsiran teologis antara Sunni dan Muktazilah tentang hubungan antara zat Allah dan sifat-Nya, contoh konkrit dalam kasus ini. Muktazilah mengatakan bahwa al-Qur'an adalah mahluk, karenanya tidak kekal, sementara Sunni mengganggapnya kekal dan melekat pada diri Allah. Jika perbedaan penafsiran ini berlanjut pada sesat-menyesatkan, dan apalagi didukung oleh kekuasaan, maka sudah pasti aliran atau mazhab yang dianggap sesat akan bernasib sial. Mereka dapat jadi dikucilkan dan tidak jarang dimusuhi dan dikejar-kejar. Sejarah Islam memiliki contoh yang sangat kaya tentang masalah ini. Ketika aliran Muktazilah berkuasa pada abad IX Masehi, seluruh mazhab dan aliran teologi yang tidak sejalan dianggap sesat dan dimusuhi. Komunitas intelektual Muktazilah, semacam MUI sekarang ini, membangun suatu lembaga inkuisisi yang disebut Mihnah, di mana orang yang memiliki keyakinan berbeda dengan yang disahkan negara ditangkap, disiksa, dan dipenjarakan. Para pengikut aliran Sunni paling banyak yang menjadi korban, di antaranya adalah Imam Ahmad bin Hambal, pendiri madzhab Hambali yang sangat dihormati. ${ }^{26}$

Persoalan ini akan lebih rumit lagi jika yang dijadikan contoh agama-agama lokal. Dalam agama lokal, rumusan ajaran pokok agamanya atau keyakinannya terkadang tidak terdefinisikan secara jelas, dan berbeda-beda antara penganut yang satu dengan penganut yang lain. Karenanya, rumusan pokok-pokok ajaran agama bersifat mutlak bagi suatu kelompok dapat jadi dianggap relatif oleh kelompok lain. Konsekuensi dari problem ini, apa yang dianggap menyimpang bagi suatu kelompok belum tentu dianggap menyimpang bagi kelompok lain. Menurut mereka, apabila negara mengambil satu bentuk tafsir pokok-pokok ajaran agama dari kelompok tertentu, maka negara telah melakukan diskriminasi terhadap kelompok lain yang memiliki pokok ajaran agama berbeda. ${ }^{27}$

\footnotetext{
${ }^{25}$ Wawancara dengan Munir Mulkhan pada tanggal 4 Mei 2010. Telusuri lebih lanjut dalam, Abdul Munir Mulkhan, "Geger Ahmadiyah", dalam Ahmad Suaedy, et.al., (ed.), Kala Fatwa Jadi Penjara, The Wahid Institute, Jakarta, 2006, hlm. 169.

${ }^{26}$ Pernyataan Luthfi Assyaukanie sebagai Ahli pada sidang judicial review terhadap UU Nomor 1/PNPS/1965 tentang Penyalahgunaan dan/atau Penodaan Agama pada tanggal 10 Februari - 24 Maret 2010. Bandingkan dengan Rumadi, “Pornografi': Kekuasaan Beragama”, dalam Ibid., hlm. 179.

${ }^{27}$ Bahkan Febi Yonesta mengilustrasikan tindakan MUI yang menyesatkan ajaran keagamaan tertentu sama dengan tindakan Geerts Wilders_-dari Partai Kebebasan anti immigrasi_yang membuat film "Fitna" untuk mendeskriditkan ajaran Islam. Film ini telah memberikan citra buruk/ stigma kepada ajaran tertentu yang dalam hal ini adalah Islam. Wawancara pada tanggal 28 Februari 2010.
} 


\section{Fatwa harus dipahami sebagai Pendapat Hukum}

Kata fatwa (kemudian disebut dalam istilah bahasa Indonesia) sepadan dengan kata ifta ${ }^{\prime}$ yang berakar dari kata afta. Ia berarti penjelasan tentang suatu masalah. ${ }^{28}$ Dalam tinjauan terminologi hukum Islam, istilah tersebut didefinisikan dengan penjelasan mengenai hukum Islam. ${ }^{29}$ Definisi fatwa kerap disebut secara inheren dengan pengertian subjeknya, mufti, yakni pemberi informasi tentang hukum hukum Islam. ${ }^{30}$ Istilah lain yang kerap disebut bersamaan dengan fatwa adalah istifta, dan mustafti. Istilah pertama, berarti aktifitas permohonannya, sedangkan istilah kedua adalah pemohon informasinya (baca: koresponden). Dengan definisi demikian, maka fatwa lebih bersifat informatif (pendapat hukum) dan tidak memiliki kekuatan hukum yang mengikat. ${ }^{31}$

Berbeda dengan al-qada', putusan hakim, meskipun sama-sama dalam bingkai pemberian informasi, tetapi ia memiliki kekuatan hukum yang mengikat. Al'Utsaiman (W. 1421 H.) mengatakan bahwa qadli, subjek al-qadla' (hakim), berbeda dengan mufti dalam dua hal, yakni netralitas dan keterikatan hukum. Yang dimaksud dengan netralitas di sini adalah independen dari pihak-pihak yang berperkara. Sedangkan maksud dari keterikatan hukum adalah bahwa apa yang menjadi putusan dari seorang qadli (hakim) mengikat (berlaku) bagi pihak yang berperkara. ${ }^{32}$

Meskipun mufti hanya diposisikan sebagai informan terkait persoalan hukum syara', para intelektual muslim secara umum memberikan kriteria khusus yang harus dimiliki oleh seorang mufti, berikut metode dan etikanya. Sehingga, tidak sembarang orang mengeluarkan fatwa, dan tidak sembarang fatwa di-publish secara bebas. Kriteria mendasar yang harus dimiliki oleh seorang mufti adalah mengetahui selukbeluk persoalan hukum. Pengetahuan hukum ini memiliki cakupan yang sangat

${ }^{28}$ Ali bin Muhammad al-Jurjani, Kitab al-Ta'rifat, al-Haramain, Jeddah, tt, hlm. 32.

${ }^{29}$ Menurut Muhammad bin Hasan al-Jaizani termasuk dalam istilah tersebut adalah perihal yang diinformasikan oleh mufti mengenai bunyi teks al-Qur'an maupun hadis, konsensus publik, dan hasil istinbat dan ijtibad-nya. Lihat: Muhammad bin Hasan bin Hasan al-Jaizani, Ma'alim Ushul al-Fiqib 'inda Abl al-Sunnah wa al-Jama'ah (Ttt:Tp, 1427 H.), hlm. 127

${ }^{30}$ Lihat: Muhammad bin Shalih bin Muhammad al-'Utsaiman, Syarah al-Ushul min Tlm al-Ushul (Bairut: Dar alHaramain, 2006), hlm. 504., Abu Ishaq Ibrahim bin Ali bin Yusuf al-Syairazi, al-Luma' fi Ushul al-Fiqh, Dar al-Kutub al-'Tlmiyah, Bairut, 2003, hlm. 127.

${ }^{31}$ Baca: Muhammad al-Hasan al-Dudi al-Sya'qaity, Syarah al-Waraqatfi Ushul al-Fiqh, juz V, hlm. 19 dalam http:/ /www.islamweb.net

${ }^{32}$ Muhammad bin Shalih bin Muhammad al-'Utsaiman, Syarah al-Ushul min..., hlm. 504-505. Perbedaan tersebut sekaligus menegaskan bahwa mufti dimungkinkan untuk memiliki tendensi terhadap suatu kelompok tertentu. Begitu juga mengenai keterikatan fatwa-nya, ia tidak dapat berlaku sebagai produk hukum yang harus dijalankan. 
luas, seperti pengetahuan tentang teks al-Qur'an yang membicarakan halal-haram, hadis-hadis tentang hukum, berikut metode memahami al-Qur'an dan hadis. ${ }^{33}$

Tidak hanya mufti yang diatur sedemikian rupa, begitupun dengan kegiatan fatwa-nya. Al-`Utsaiman melansir beberapa syarat yang harus dipenuhi dalam berfatwa, yaitu: pertama, jika mufti mengetahui hukum yang rajih sesuai dengan keyakinan atau dugaannya; kedua, deskripsi permasalahannya dapat digambarkan secara jelas dan sempurna hingga ia mendapatkan hukum yang sesuai; ketiga, keberadaan mufti harus benar-benar netral agar dapat mendeskripsikan dan merelevansikan permasalahannya dengan dalil-dalil syara'. Karenanya, dalam kondisi yang tidak netral, seorang mufti tidak boleh mengeluarkan fatwa. Jika terdapat persoalan baru yang bersifat mendesak dan segera butuh jawaban hukum, maka mufti wajib mengeluarkan fatwanya, begitupun pada saat mustafti menanyakan suatu persoalan meskipun hanya dalam bingkai menutup rasa ingin tahu (baca; belajar). Kondisi terakhir ini lebih disebabkan karena tidak deperkenankannya untuk menyembunyikan pengetahuan (kitman al-'ilm). ${ }^{34}$

Instrument lain dalam persoalan fatwa adalah mustafti (koresponden). Dalam bingkai hukum Islam, koresponden juga memiliki ketentuan yang harus dipenuhi, yakni termasuk dalam kategori muqallid, seseorang yang tidak memiliki kemampuan untuk berijtihad secara mandiri. ${ }^{35}$ Karena itu, bagi setiap muslim yang memiliki kapabilitas dalam berijtihad tidak diperkenankan untuk meminta fatwa kepada orang lain.

\section{Penutup}

Berdasarkan hasil penelitian tersebut di atas, maka pandangan masyarakat terhadap Fatwa MUI tentang Aliran Sesat Keagamaan di Indonesia dapat

\footnotetext{
${ }^{33}$ Termasuk dalam hal ini adalah pengetahuan tentang persoalan hakikat-majas' 'am-khas, mujmal-mufassall, mutlakmuqayyad, mantuq-mafhum, nasikh-mansukh, kesepakatan dan perbedaan pendapat ulama' kuna, pendapat-pendapat yang dapat dijadikan pegangan dan tidak, persoalan qiyas (analogi), ijtibad, dan lain sebagainya. Baca lebih lanjut dalam: Abu Ishaq Ibrahim bin Ali bin Yusuf al-Syairazi, al-Luma' fi Ushul..., hlm. 127. Mendekati pendapat tersebut adalah alSyanqaity dalam karya Komentar atas Waraqat-nya, menurutnya mufti harus memenuhi tiga syarat sebagi berikut: pertama, mufti harus pakar dalam persoalan pokok dan cabang fikih; kedua, mufti harus secara sempurna telah menguasai perangkat yang dibutuhkan dalam melakukan ijtihad; ketiga, mengetahui tentang apa yang dibutuhkan dalam melakukan penggalian hukum, seperti penguasaan linguistik, tarikh al-ruwat, tafsir dan ragam informasi yang berkaitan dengan ayat-ayat hukum. Muhammad al-Hasan al-Dudi al-Sya'qaity, Syarah al-Waraqat fi.., juz V, hlm. 19.

${ }^{34}$ Baca: Muhammad bin Shalih bin Muhammad al-'Utsaiman, Syarah al-Ushul min ..., hlm. 505-514.

${ }^{35} \mathrm{Al}$-Syanqaity membatasinya dalam level mujtabid mutlaq. Artinya, ragam mujtahid lain yang berada di bawah levelnya diperkenankan untuk melakukan taqlid, hal ini pun dibatasi hanya dalam persoalan-persoalan tertentu, seperti taqlid dalam persoalan kaidah dan ushul, status kualitas nash, dan jarh dan ta'dll. Muhammad al-Hasan al-Dudi al-Sya'qaity, Syarah al-Waraqat fi.., juz V, hlm. 20.
} 
disimpulkan; Pertama, Sebagian masyarakat mendukung penuh terhadap fatwa MUI tentang Aliran Sesat Keagamaan. Karena tugas utama MUI adalah menunjukan mana yang sesat dan mana yang tidak, mana yang haram dan mana yang tidak, mana yang sah dan mana yang tidak. Jika tugas ini diabaikan oleh MUI, maka MUI sudah kehilangan fungsinya sebagai pewaris Nabi. Mereka juga sepakat jika tindakan sesat dan menyesatkan itu dapat dikriminalisasi. Karena hal ini mendapat legitimasi dari berbagai peraturan perundang-undangan yang berlaku seperti UU No. 1 PNPS/ 1965 dan KUHP Pasal 156 a. Sebagian masyarakat dapat menerima fatwa sesat keagamaan tersebut, MUI menurutnya berhak untuk menyesatkan aliran seimannya yang dianggap menyimpang dari ajaran mainstream. Tetapi mereka tidak sepakat jika pengikut aliran yang disesatkannya itu kemudian hak-hak civilnya menjadi dibatasi apalagi dikurangi. Negara Kesatuan Republik Indonesia adalah Negara Hukum berdasarkan Pancasila. Negara hukum Pancasila adalah bukan negara sekuler dan bukan negara agama, sehingga negara tidak memiliki mata Tuhan yang dapat menilai ajaran itu sesat atau tidak. Sebagian yang lain menentang terhadap Fatwa tersebut, MUI tidak memiliki otoritas untuk menentukan sebuah aliran keagamaan atau keyakinan itu sesat atau tidak. Hak untuk menentukan sebuah aliran itu sesat atau tidak hanya prerogatif Tuhan. Sehingga jika hak ini diambil alih oleh MUI, maka lembaga ini telah melakukan pelanggaran hukum dan HAM.

Negara dalam hal ini pemerintah harus sesegera mungkin untuk melakukan harmonisasi terhadap sejumlah peraturan perundang-undangan, khususnya yang terkait dengan hak kebebasan beragama. Pembatasan terhadap hak-hak ini harus dipandang sebagai perlindungan terhadap hak-hak lain yang bersifat asasi. Di negara hukum Indonesia tidak boleh atas nama hak kebebasan kemudian mengorbankan hak-hak dan martabat orang lain yang bersifat mendasar. Sebaliknya, negara pun tidak boleh terlalu jauh mengintervensi hak kebebasan ini, apalagi yang berhubungan dengan pemahaman/ penafsiran dari ajaran-ajaran teologi masingmasing penganutnya. Pemahaman dan penafsiran baru dapat dibatasi jika sudah berada di forum externum dan itu pun apabila mengganggu keselamatan, ketertiban, kesehatan, moral dan hak-hak mendasar masyarakat. Untuk masyarakat dan khususnya ormas keagamaan sudah seharusnya menyadari bahwa fatwa itu hanya sebatas legal opinion, bukan keputusan hukum yang bersifat mengikat. Dengan demikian jika hanya baru disesatkan oleh MUI, masyarakat tidak perlu melakukan tindakan main hakim sendiri. Masyarakat harus menyadari bahwa tindakan 
kekerasan dan intoleransi terhadap orang lain lebih kejam dan buruk dibandingkan dengan mereka yang dianggap sesat itu sendiri.

\section{Daftar Pustaka}

Al Khanif, Hukum Kebebasan dan Kebebasan Bergama Di Indonesia, LaksBang Mediatama, Yogyakarta, 2010.

al-`Utsaiman, Muhammad bin Shalih bin Muhammad, Syarah al-Ushul min 'Ilm alUshul, Dar al-Haramain, Bairut, 2006.

al-Jaizani, Muhammad bin Hasan bin Hasan, Ma'alim Ushul al-Fiqih 'inda Ahl al-Sunnah wa al-Jama'ah, Ttt:Tp, $1427 \mathrm{H}$.

al-Jurjani, Ali bin Muhammad, Kitab al-Ta'rifat, al-Haramain, Jeddah, tt.

al-Sya' qaity, Muhammad al-Hasan al-Dudi, Syarah al-Waraqat fi Ushul al-Fiqh, juz V, dalam http://www.islamweb.net

al-Syairazi, Abu Ishaq Ibrahim bin Ali bin Yusuf, al-Luma' fi Ushul al-Figh, Dar alKutub al-'Ilmiyah, Bairut, 2003.

Center For Religious And Cross-Cultural Studies Sekolah Pascasarjana, Universitas Gajah Mada Yogyakarta, “Laporan Tahunan Kehidupan Bergama Di Indonesia $2009^{\prime \prime}$.

Hebblethwaite, Peter, The New Inquisition, Schillebeeckx and Küng, Fount Paperbacks, London, 1980.

John, Olle, “The Campign Against 'Heresy' State and Society in Negotiation in Indonesia", makalah yang disampaikan dalam $16^{\text {th }}$ Biennial Conference of the Asian Studies Association of Australia di Wollongong pada 26-29 Juni 2009.

Mas'udi, Masdar F., Kala Fatwa Jadi Penjara, The Wahid Institute, Jakarta, 2006.

Mulia, Siti Musda "Potret Kebebasan Beragama Dan Berkeyakinan Di Era Reformasi" dalam Elza Peldi Taher, Merayakan Kebebasan Beragama, Bunga Rampai 70 Tahun Djohan Effendi, Jakarta: Indonesian Conference on Religion and Reance, 2009

Niaz A, Shah,. "Freedom of Religion: Koranic and Human Rights Perspectives" dalam Asia-Pacific Journal on Human Rights and the Law 1 \& 2, 2005.

Setara Institute, “Tiga Tahun Laporan Kondisi Kebebasan Bergama/ Berkeyakinan di Indonesia".

Suaedy, Ahmad, et. al., Islam, Konstitusi dan Hak Asasi Manusia, Problematika Hak Kebebasan Beragama dan Berkeyakinan di Indonesia, The Wahid Institute, Jakarta, 2009

Sudarto, Rm. Gregorius Tulus Pr, Daftar Hitam Gereja Katolik, Fidei Press, Jakarta, 2009. 
Suteki, “Rekonstruksi Politik Hukum Tentang Hak Menguasai Negara Atas Sumber Daya Air Berbasis Nilai Keadilan Sosial (Studi Privatisasi Pengelolaan Sumber Daya Air". Disertasi pada Program Doktor Ilmu Hukum Universitas Diponegoro Semarang, 2008.

The Wahid Institute, "Anual Report Kebebasan Beragama dan Kehidupan Keagamaan di Indonesia Tahun 2009". 